\title{
VAIIDITY OF CONTRACTS NOT TO COMPETE
}

\author{
Charles E. Carpenter \\ IN GENERAI
}

(a) In Early English Law. The early English cases in restraint of trade are actions upon covenants in bonds by which the obligor agreed not to exercise his trade in a more or less restricted territory. These cases seem to make no point of the narrowness of the restriction either as to space or time, but treat all such covenants as void. Thus a condition in a bond by the defendant not to use his art of a dyer's craft within the plaintiff's town for half a year was held invalid, the court saying, "And per Dieu, if the plaintiff were here he should go to prison until he paid a fine to the King." 1 Other early cases holding such covenants void are the Blacksmith's case, ${ }^{2}$ where one blacksmith agreed with another of the same town not to carry on his trade within the town; Colgate v. Bacheler, ${ }^{3}$ where a haberdasher agreed that for a period of four years he would not carry on his trade in the county of Kent; and an anonymous case ${ }^{4}$ where an apprentice at the time of his apprenticeship agreed not to employ his craft for four years at Nottingham.

Not only did the early cases attach no importance to the narrowness or the generality of the restriction, but they made no distinction as to whether the contract was a bare one not to compete, or was made as part of a contract for a term of employment, or as ancillary to the sale of a business. The reasons for holding contracts not to engage in a trade or employment void were not stated in the early cases, but the objections to such covenants are not difficult to surmise when it is remembered that at that time there were few trades a man could follow without having been duly apprenticed, and that there were perhaps no other trades in which he was competent; and when it is remembered that follow-

\footnotetext{
${ }^{1}$ Anonymous, Y. B. 2 Hen. V, pl. 26 (14I5).

$2_{2}$ Leo. 210, 3 Leo. 217 (1587).

'Cro. Eliz., 872 (I596).

- Moore II5 (I578).
} 
ing the Great Plague, which carried off so many workmen and servants, the Statute of Laborers ${ }^{5}$ was passed in I349, requiring every able-bodied person under sixty years of age "not living in merchandise nor exercising any craft, nor having of his own whereof he may live, nor proper land about whose tillage he may himself occupy and not serving any other," to serve him that required it, under penalty of being committed to gaol. Under these conditions it is apparent that an agreement not to carry on a trade or to refrain from competing with the covenantee might have greatly injured the covenantor by divesting him of his only means of earning a livelihood; and it might have been in effect an agreement to violate the Statute of Laborers.

The earliest case which the writer has found sustaining an agreement not to exercise a trade is that of Rogers $v$. Parry, ${ }^{6}$ where the defendant was held liable in assumpsit upon an agreement not to carry on his trade as a joiner in a shop, which was demised to him, for twenty-one years. But it does not appear that the plaintiff lessor placed this restriction upon the use of the shop by the defendant to prevent him from competing with a business which he retained, hence the interest which the plaintiff sought to protect may have been only the peaceful enjoyment of the house in which he continued to live, the shop leased being merely parcel of the house.

But the English courts early supported agreements not to compete where they were part of a sale of property or a business, and were appropriate as a protection of the property or business retained or sold and where the restraints imposed upon the covenantor were narrow and not general. Thus we find in 1620 a court upholding a promise not to keep shop in Newport, made by the defendant, a shopkeeper, as part of a sale of all of his wares to the plaintiff, who kept a shop nearby, selling similar wares. ${ }^{7}$ And so a promise by the defendant not to carry on her trade in Bassingtooke was supported where the promise was made as a part of defendant's assignment to the plaintiff of her shop as part considera-

${ }^{5} 23$ Edw. III (1349).

'2 Bulst. 136 (1613).

'Broad v. Jollyfe, Cro. Jac. 596 (I620). 
tion of a marriage between the plaintiff and her daughter. ${ }^{8}$ The first case to go extensively into the reasons for holding contracts not to compete valid where made a part of a sale of a business was Mitchel $v$. Reynolds. ${ }^{9}$ In that case the defendants assigned to the plaintiff the lease of a bakeshop for a term of five years, during which they agreed not to exercise the trade of baker in the parish. Among the reasons which the court gave in its examination of the subject for contracts not to compete being held invalid were that such covenants, if enforcible, would deprive the covenantor of the means of livelihood, his family of subsistence, and the public of a useful member. It also mentioned as an objection the tendency which such covenants had to produce a monopoly. ${ }^{10}$

(b) Partial and General Restraints. The distinction taken in Mitchel $v$. Reynolds holding all general restraint void and particular or partial restraints valid if upon a good and adequate consideration, or, as is expressed in the later cases, "if reasonable," persisted in the English law until after I870. In Ward $v$. Byrne, ${ }^{11}$ the defendant gave a bond to the plaintiff, a coal merchant in London, by which, after reciting that the plaintiff, at the request of the defendant, had received and taken the defendant into his service in the capacity of town-traveller and collecting clerk, it was conditioned inter alia that the defendant should not, within two years after leaving the plaintiff's service, solicit or sell to any customers of the plaintiff; that he should not follow or be

\footnotetext{
${ }^{8}$ Prugnell v. Goss, Aleyn 67 (I648).

i P. Wms. I8I (I7II).

${ }^{10}$ The court said: "The true reasons for the distinction upon which the judgments in these cases of voluntary restraints are founded are, first, the mischief which may arise from them, first to the party by the loss of his livelihood and the subsistence of his family, and secondly to the public, by depriving it of an useful member. Another reason is the great abuses these voluntary restraints are liable to; as for instance, from corporations who are perpetually laboring for exclusive advantages in trade, and to reduce it into as few hands as possible; as likewise from masters, who are apt to give their apprentices much vexation on this account, and to use many indirect practices to procure such bonds from them, lest they should prejudice them in their custom, when they come to set up for themselves. Thirdly, because in a great many instances, they can be of no use to the obligee; which holds in all cases of general restraint throughout England; for what does it signify to a tradesman in London, what another does at Newcastle? And surely it would be unreasonable to fix a certain loss on one side, without any benefit to the other." Supra note 9, at 190.

${ }^{11} 5$ M. \& W. 549 (1839).
} 
employed in the business of a coal merchant for nine months after he should have left the employment of the plaintiff; and that he should not leave his employment without giving a month's notice. It was held on motion in arrest of judgment that the bond was void, on the ground that this was in restraint of trade unlimited in point of space; the court saying, "But when a general restriction limited only as to time is imposed, the public are altogether losers for that time of the services of the individual, and do not derive any benefit whatever in return; and looking at the authorities cited upon this subject, it does not appear that there is one clear authority in favour of a total restriction on trade, limited only as to time . . . It seems to me, therefore, that there is no authority in favor of the position that there can be a general restriction, limited only as to time, and that this case falls within the rule laid down by Tindal, C. J., viz., that this is a general prohibition against carrying on trade, which is more extensive than the interests of the party with whom the contract is made can possibly require." And in Allsopp v. Wheatcroft, ${ }^{12}$ where a clerk covenanted that he would not during his service or within two years afterward sell any Burton ale or beer other than that brewed by the plaintiffs, it was held the covenant was void as being too extensive, the court saying, "No doubt, in the case of Leather Cloth Company v. Lorsont, Lord Justice (then Vice-Chancellor) Jamis threw some doubt on the existence of a hard and fast rule which makes a covenant in restraint of trade invalid if unlimited in area; but there were expressions in the instrument in that case limiting the generality of the covenant, and it was in substance a case of a different class from this. . . . Assenting, as I do, to everything that was said in Leather Cloth Company v. Lorsont, I can hardly treat it as authorizing me to depart from the recognized rule as to limitation of space in a case so different from it as the present is, and unless that rule be departed from, the covenant here is clearly bad."

The court further said, "It seems to me that, according to the view taken in the cases, it could not have been held necessary for the plaintiffs' protection to prevent the defendant from solicit-

${ }^{12}$ L. R. I5 Eq. 59 (1872). 
ing orders for the ale of other Burton brewers in places where Burton ale had never been sold or heard of, and probably, as Mr. Pearson argued, the covenant would, even within the limits where Allsopp's company had customers, prevent lawful acts of the defendant which would not injure the plaintiff. I am bound by the authorities to hold the covenant inoperative independently of any absolute rule requiring a limitation of area." 13 However, the rule that the covenant not to compete shall be limited as to space was slowly absorbed in the rule of reasonableness, gradually growing in favor. Under this the test for determining the validity of the covenant is whether the restraint is wider than is necessary to protect the promisee in the property or business sold or retained. In Rousillon $v$. Rousillon ${ }^{14}$ the court said that there existed no rule "that the contract shall be limited as to space over and above the rule that the contract shall be reasonable;" and the matter was finally set at rest by the House of Lords in Nordenfelt v. Maxim Nordenfelt, etc: Co., ${ }^{15}$ where the defendant, who sold to the plaintiff his business of manufacturing guns and ammunition for war purposes, and covenanted not to engage in the business directly or indirectly for twenty-five years, was enjoined from breach of the covenant though it was world wide in extent, since the business was of such wide dimensions as to require a restraint unlimited in space. ${ }^{16}$

In the United States the cases upholding contracts not to compete are legion when the restraint is partial and not unreasonable; ;7 but the struggle to break away from the distinction be-

${ }^{13}$ See also Hinde v. Gray, I M. \& G. I94 (I840).

${ }^{14}$ I4 Ch. D. 35I (I880).

${ }^{15}$ [1894] A. C. 535.

${ }^{20}$ More recent English cases in accord are Goldsoll v. Goldman, [1914] 2 Ch. 603; Herbert Morris Co. v. Saxalby, [1916] A. C. 688, 701.

${ }^{17}$ Besides the cases cited in notes $27,28,32,33,35,36$ and 37 infra, see also United States v. Addyston Pipe \& Steel Co., infra note 39; American Brake Beam Co. v. Pungs, I4I Fed. 923 (C. C. A. 7th, I905); McCurry v. Gibson, 108 Ala. 45I, I8 So. 806 (I895); Swigert \& Howard V. Tilden, 12I Iowa 650,970 N. W. 82 (I903) ; Heinz v. Roberts, I35 Iowa 748 , 110 N. W 1034 (1907); Kochenrath v. Christman, 180 Ky. 799, 203 S. W. 738 (I918); New York Bank Note Co. v. Kidder Press Mfg. Co., I92 Mass. 403, $78 \mathrm{~N}$. E. 463 (1906); Old Corner Book Store, Inc. v. Upham, I94 Mass. I05, 80 N. E. 228 (I907); National Ben Co. v. Union Hospital Co., 45 Minn. 272, 47 N. W. 806 (I89r); Kronschnabel-Smith Co. v. Kronschnabel, 87 Minn. 230, 9r N. W. 892 (I902); Williams v. Thomson, I43 Minn. 454, I74 N. W. 307 (I927); 
tween particular or partial and general restraints still persists. There are a number of cases holding contracts by a seller of a business not to engage in a similar business throughout the entire state to be invalid because they are in general restraint of trade. ${ }^{18}$ Thus in Taylor $v$. Blanchard ${ }^{19}$ the plaintiff and defendant carried on a partnership, during which the defendant became acquainted with the business and its customers. They dissolved partnership, the defendant selling out to the plaintiff and agreeing not to carry on in any place in Massachusetts the business of manufacturing and selling shoe cutters, which was the business the partnership had conducted. The plaintiff contended that the restraint ought not to be held bad, saying, "A monopoly extending throughout the state may be as really injurious to the people of the state as if it extended throughout the country." 20 In Union Strazeboard Co. v. Bonfield, ${ }^{21}$ where a seller of a manufacturing business covenanted not to engage in that business for a period of twenty-five years in the state of Illinois when so doing might conflict with the business interests or lessen the profits of the buyer, the court held the covenant bad, saying, "The restrictions imposed by this contract are probably no greater than necessary to prevent competi-

Wills v. Forester, I40 Mo. App. 32I, I24 S. W. I0go (I910) ; Kramer v. Old, IIg N. C. I, 25 S. E. 813 (I897); Faust v. Rohr, I66 N. C. I87, 8I S. E. I096 (I9I4) ; Bradshaw v. Milliken, I73 N. C. 432, 92 S. E I6I (I9I7) ; Mar-hof Co., Inc. v. Rosenbacher, infra note 52 ; Melick v. Foster, 64 N. J. L. 394, 45 Atl. 9II (I900) ; Nachamkis v. Goldsmith et al., Ior N. J. L. 356, I28 Atl. 238 (I925); Marvel v. Jonah, 83 N. J. Eq. 295, 90 Atl. I004, (I914), see note in L. R. A. I9I5B 206; Underwood v. Smith, I9 N. Y. Supp. 380 (I892); Niles v. Fenn., I2 Misc. 470, 33 N. Y. Supp. 857 (I895) ; Brett v. Ebel, 29 App. Div. 256,5 I N. Y. Supp. 573 (I898); Ru Ton v. Everitt, 35 App. Div. 412,54 N. Y. Supp. 896 (I898) ; Blauner v. Williams Co., infra. note 52; Excelsior Quilting Co. v. Creter, 36 Misc. 698, 74 N. Y. Supp. 36r (I902) ; American Ice Co. v. Meckel, I09 App. Div. 93,95 N. Y. Supp. I060 (I905); Broadbrooks v. Tolles, II4 App. Div. 646, 99 N. Y. Supp. 996 (1906); James Van Dyk Co. v. F. V. Reilly Co., 73 Misc. 87, I30 N. Y. Supp. 755 (IgII); Komow v. Simplex ClothCutting Machine Co., Inc., Iog Misc. 358, 179 N. Y. Supp. 682 (1919) ; Pittsburgh Stove \& Range Co. v. Penn. Stove Co., 208 Pa. 4I, 57 Atl. 77 (I904); Boggs v. Friend, 77 W. Va. 531, 87 S. E. 872 (I916); My Laundry Co. v. Schmeling, I29 Wis. 527, I09 N. W. 540 (1906); Kradwell v. Thiesen, I3I Wis. 97 , III N. W. 233 (I907); Lazar v. Berg, I79 Wis. 6ro, I9I N. W. 966 (1923).

${ }^{28}$ Harding v. Glucose Co., I82 I11. 55I, 55 N. E. 577,64 L. R. A. 738 (1899); Lanzit v. Sefton Mfg. Co., I84 Iil. 326,56 N. E. 393 (I900).

10 I3 Allen 370 (Mass. I866).

${ }^{20}$ See also Bishop v. Palmer, I46 Mass. 464, I6 N. E. 299 (I888) ; Hand-

forth v. Jackson, I50 Mass. I49, 22 N. E. 634 (1889).

${ }^{2}$ I93 I11. 421, 6I N. E. I038 (Igor). 
tion with the Union Strawboard Company in its business, but that is not the only test of its validity. If it should be conceded that the contract is divisible, the question then is, under this declaration, whether it can be enforced as to the entire state of Illinois. Counsel contend that it is valid to that extent, at least, and that the rule stated on that subject in the cases above cited should not be adhered to. The reason for the rule is that it is against the policy of the state that the people of the whole state should be deprived of the industry and skill of a party in an employment useful to the public, and he should be compelled either to engage in other business or abandon his citizenship of the state and remove elsewhere in order to support himself and family. The argument is that a contract, to be in general restraint of trade, must extend to the entire realm of the United States, which would not be deprived of the industry of the citizen or of his citizenship unless he were compelled to go to a foreign country. Within its own sphere the state has a public policy as a commonwealth, which the courts of the state regard and enforce, distinct from questions of policy affecting the nation at large. The state regulates its internal affairs, supports those who become public charges, and is interested in the industries of its citizens. It is against the policy of the state that its citizens should not have the privilege of pursuing their lawful occupations at some place within its borders, and that a citizen should be compelled to leave the state to engage in his business and to support himself and family. It is true that a contract may be valid which embraces portions of more than one state. Trade and business are not affected by state lines, and a contract might be good in restraint of trade which embraced within reasonable limits, parts of different states, but an agreement which applies to the whole state is void, and cannot be enforced. ${ }^{22}$

In California by code provision ${ }^{28}$ a contract restraining

${ }^{23}$ Supra note I8.

${ }^{23}$ CAL. Crv. Code (Deering, 1923) §§ $1673,1674,1675$ :

"Contract in restraint of trade, void. Every contract by which any one is restrained from exercising a lawful profession, trade, or business of any kind, otherwise than is provided by the next two sections, is to that extent void." 
trade throughout the entire state is invalid. These statutory provisions have been copied in North Dakota, ${ }^{24}$ South Dakota, ${ }^{25}$ and Oklahoma. ${ }^{26}$ In Massachusetts the later decisions have rejected the rule that a contract restraining trade throughout the state is invalid, and there are dicta to the effect that a covenant unlimited both as to space and time may be valid. ${ }^{27}$. In the New York case of Dianond Match Co. v. Roeber, ${ }^{28}$ it was held that a covenant was not general which did not cover the whole of the United Stat $\epsilon \mathrm{s}^{20}$ Many states expressly reject the state limit; ${ }^{30}$ and Illinois is the only state except those having a statute to the contrary where an extension of restraint throughout the entire state in itself makes the contract bad.

There are many cases where covenants imposing restraints throughout the whole of the United States have been treated as void ${ }^{31}$ because they constitute a general restraint of trade. But

"Exception in favor of sale of good-will. One who sells the good-will of a business may agree with the buyer to refrain from carrying on a similar business within a specified county, city, or a part thereof, so long as the buyer, or any person deriving title to the good-will from him, carries on a like business therein."

"Exception in favor of partnership arrangements. Partners may, upon or in anticipation of a dissolution of the partnership, agree that none of them will carry on a similar business within the same city or town where the partnership business has been transacted, or within a specified part thereof."

1 dist

Cavasso v. Downey, 45 Cal. App. 780, I88 Pac. 594 (I920) ; Chamberlain v. Augustine, $172 \mathrm{Cal}$. 285, I56 Pac. 479 (1916); Davis v. Jointless Fire Brick Co., 300 Fed. I (C. C. A. 9th, I924).

${ }^{24}$ N. D. CoMr. Laws ANN. (IgI3) $\$ \$ 5928-5930$.

${ }^{25} \mathrm{~S} . \mathrm{D}$. REv. CODE (I9I9) $\S \S 898-900$.

“ OKIA. REv. Laws (I92I) \$\$ 978-980.

${ }^{2}$ Anchor Electric Co. v. Hawks, I7I Mass. IoI, 50 N. E. 509 4I I. R. A. I89 (I898); United Shoe Machinery Co. v. Kimball, I93 Mass. 35I, 358, 79 N. E. 790 (Ig07); Marshall Engine Co. v. New Marshall Engine Co., 203 Mass. $410,424,89$ N. E. 548 (1909).

${ }^{23}$ I06 N. Y. 473, I3 N. E. 419 (I887).

$\approx$ Exclusion of Nevada and Montana was held to preclude objection on ground of covenant being general.

${ }^{80}$ Newell v. Meyendorff, 9 Mont. 254, 23 Pac. 333, 8 L. R. A. 440 (I890); Herreshoff v. Bontmeau, I7 R. I. 3, I9 Atl. 712 (I890).

"All courts which hold the covenant for a restraint covering an entire state had, as in notes $20-23$ supra, would necessarily treat a more general restraint bad. Callahan v. Donneolly, 45 Cal. I52 (1872); Gamewell Fire Alarm Tel. Co. v. Crane, infra note 40 . (this doctrine is repeated in later Massachusetts cases, see note 27 supra); Hungerforth v. Jackson, I50 Mass. I49, 22 N. E. 634 (1893) ; Ropes v. Upton, I25 Mass. 258 (1878) ; Boutelle v. Smith, II6 Mass. Irr (1874), (but see also Morse Twist Drill Co. v. Morse, I03 Mass. 
logical adherence to the principle that a restraint is valid if it is no more extensive than the legitimate interests of the promisee demand, requires a repudiation of the distinction between partial and general restraints; and many recent decisions in the United States adopting this test of reasonableness of the restraint seem to favor the validity of covenants unlimited as to space. ${ }^{\mathbf{3 2}}$

While a failure to limit the restraint as to space will in many states, even though the restraint is not greater than the protection which the legitimate interests of the covenantee demands, render the contract invalid, a similar failure to limit the restraint as to time will not everywhere invalidate the contract $;^{33}$ though in some

73 (1869)) ; Roberts v. Lemont, 73 Nebr. 365, I02 N. W. 770 (I905) (unlimited in time and space, void); Wyder v. Milhomme, infra note, 75, semble; Maier v. Homain, 4 Daly I68 (N.Y. I87I); Taylor v. Saurman, IIO $\mathrm{Pa} \mathrm{3}$, I Atl. 40 (I885) (dictum, contracts too unlimited as to space, void). In Caswell v. Gibbs, 33 Mich. 33I (1875), an agreement never to tow vessels in competition with the plaintiff was held to be too indefinite and uncertain in character to be enforcible. See note 13 Am. Rep. 173; and also American Laundry Co. v. E. W. Dry Cleaning Co., I99 Ala. 154, 74 So. 58 (1917) ; Boone v. Burnham \& Dallas, 29I Ky. 9I, 200 S. W. 3I5 (I9I8); Hensche v. Moore, $257 \mathrm{~Pa}$. 196, IOI Atl. 308 (I917); Monongahela River Consolidated Coal and Coke Co. V. Jutle 210 Pa. 288, 59 Atl. I088, 2 Ann. Cas. 957 (1904); see Everett v. Boone, I5I Ga. 3II, I2I S. E. 240 (1924).

2 Prame v. Ferrell, 166 Fed. 702 (C. C. A. 6th, 1909); Knapp v. S. Jarvis Adams Co, I35 Fed. 1008 (C. C. A. 6th, 1905); Carter v. Alling, 43 Fed. 208 (C. C. N. D. IIl., I890); Cropper v. Davis, 243 Fed. 310 (C. C. A. 8th., I9I7); United States Chemical Co. v. Provident Chemical Co., 64 Fed. 946 (C. C. E. D. Mo., I894) ; Nat. Enameling \& Stamping Co. v. Haberman, I20 Fed. 4I5 (C. C. Conn., 1903); Hall Mfg. Co. v. Western Steel \& Iron Works, infra note 84 (unlimited either in space or time); Barrows v. McMurtry Mfg. Co., 54 Colo. 432, I3I Pac. 430 (I9I3) ; Swigert v. Tilden, I2I Iowa 650,97 N. W. 82,63 L. R. A. 608 (1903); Anchor Electric Co. v. Hawkes, Marshall Engine Co. v. New Marshall Engine Co., both stipra note 27; Western Woodenware Asso. v. Starkey, infra note 71 ; Diamond Match Co. v. Roeber, supra note 28; Leslie v. Lorrilard, I Io N. Y. 5I9, I8 N. E. 363 (I888); Good v. Daland, I2I N. Y. I, 24 N. E. 15 (1890).

${ }^{23}$ Smith v. Webb, I76 Ala. 596, 58 So. 9r3 (I9I2); American Laundry Co. v. E. \& W. Dry Cleaning Co., 199 Ala. I54, 74 So. 58 (I917); McCurry v. Gibson, I08 Ala. 45I, I8 So. 806 (I895); Webster v. Williams, 62 Ark. IOI, 34 S. W. 537 (1896); Styles v. Lyon, 87 Conn. 23, 86 Atl. 564 (I913); McAuliffe v. Vaughan, I35 Ga. 852,70 S. E. 322 (I9II); Eisel v. Hayes, I4I Ind. 4I, 40 N. E. II9 (I895); O'Neil v. Hines, I45 Ind. 32, 43 N. E. 946 (1897); Hamilton v. Ryan, Io3 Ill. App. 2I2, rev'd., 205 I1l. I9I, 68 N. E. 781 (rgo3); Arnold v. Kreutzer, 67 Iowa 214, 25 N. W. I38 (1885); Mooreman v. Parkerson, I3I La. 204, 59 So. 122, I23 (I912) ; United States Shoe Machinery Co. v. Kimball, I93 Mass. 351, 79 N. E. 790 (Igo7) ; Foss v. Roby, I95 Mass. 292, 81 N. E. 199 (I907) ; Up River Ice Co. v. Denler, II4 Mich. 296, 72 N. W. I57 (I897); Holliston v. Ernaton, I24 Minn. 49, I44 N. W. 4I5 (19I3); Gill v. Ferris, 82 Mo. 156 (I884); Kramer v. Old, II N. C. I, 25 S. E. 813 (I896); Dow v. Gotch, II3 Neb. 60, 201 N. W. 655 (I924); Caril v. Snyder, 26 AtI. 977 (N. J. I893); Scherman v. Stern, II7 At1. 631 (N. J. I922) ; Boyden v. Baldwin, I5 Misc. Rep. I03, 36 N. Y. Supp. 478 (I895); Lappano v. Marmone, Ig8 N. Y. 
states where restraint as to time is unlimited or more extensive than required for proper protection of the covenantee, the contract is rendered bad. ${ }^{34}$ In other states covenants which are unlimited are construed as meaning a reasonable time, ${ }^{85}$ or for the life of the promisee, ${ }^{36}$. or so long as the promisee continues in business. $^{37}$

(c) Reasonableness. The distinction between general and partial restraints is an artificial and technical one, for the real objections to contracts not to compete are: (I) that they divest the promisor of his means of earning a livelihood and supporting himself and family; and (2) that they deprive the community of (a) the benefit of his services and (b) the benefit which his competition might offer. It is obvious that it cannot be true that there is no force to these objections so long as the restraint is partial, but that objections suddenly arise just at the point when the restraint becomes universal. The truth is, the force of these objections increases gradually as the restraint increases in space and time, and diminishes in the same manner as the restraints decrease in space and time. If the promisor is precluded by his contract from carrying on his trade everywhere, any time in the future, these objections have their fullest force; and if the restraint is only for a small territory and for a short time none of these objections have much weight. It is not the mere fact of the universality of the restraint, but the burdensomeness of the restraint as it becomes more extensive, that gives force to these

Supp. 433 (1923) ; Stewart v. Biddele, 79 Pa. 336 (1875) ; Henschke v. Moore, infra note 34; French v. Parker, I6 R. I. 219, I4 At1. 870 (I888); Tillinghast v. Boothby, 20 R. I. 59, 37 Atl. 344 (1897); Turner v. Abbott, II6 Tenn. 718, 94 S. W. 64 (I906); Rudolph v. Graham, 254 S. W. 402 (Tex. Civ. App. 1923).

" Rakestraw v. Lanier, I05 Ga. 488, 30 S. E. 735 (1898) ; Tarr v. Stearman, 264 Ill. IIo, ro5 N. E. 957 (19I4); Ford v. Gregson, 7 Mont. 89, I4 Pac. 659 (I887); Mandeville v. Harman, 42 N. J. Eq. 185, 7 Atl. 37 (I886); Henschke v. Moore, $257 \mathrm{~Pa}$. 196, IOr Atl. 208 (IgI7); Carroll v. Giles, 30 S. C. 4I2, 9 S. E. 422 (I889); Tecktonius v. Scott, IIo Wis. 44 I, 86 N. W. 672 (Ig0I).

${ }^{25}$ Rackmann v. Riverbank Imp. Co., 167 Mass. I, 44 N. E. 990 (1896); Boggs v. Friend, 77 W. Va. 531, 87 S. E. 873 (1916).

${ }^{x}$ Saddlery, etc., Co. v. Hillsborough Mills, 68 N. H. 216, 44 Atl. 300 (I895); Hauser v. Harding, 126 N. C. 295, 35 S. E. 586 (Ig0o); see also Wooten v. Harris, I53 N. C. 43,68 S. E. 898 (Igro).

"Tarry v. Johnson, II4 Neb. 496, 208 N. W. 6r5 (1926); Weickgenant v. Eccles, I73 Mich. 695, I40 N. W. 513 (1913). 
objections. However, they have enough force that no matter how restricted the restraint is in space and time, a bare contract not to compete is invalid ${ }^{38}$ and in order that a contract not to compete may be sustained under the principle that it is a reasonable restraint, it must be "ancillary to the main purpose of a lawful contract and necessary to protect the covenantee in the en joyment of the legitimate fruits of the contract, or to protect him from the dangers of an unjust use of those fruits by another party." 39

In other words, it is apparent that the problem of determining the validity of contracts not to compete under the rule of reasonableness is a problem of balancing social interests, of setting over against the social detriment involved in restricting the promisor's activities the social advantages of protecting the promisee in legitimate interests which the contract gives him, and of enabling the covenantor advantageously to dispose of his business or services. The objections to restraint of trade, namely, that it divests the promisor of his means of earning a livelihood and of supporting himself and family, and that it deprives the community of the benefit of his services and the benefit which his competition might offer, are offset by the more important social interest involved in making goodwill of a business or other property vendible, or in protecting the covenantee in some proper interest covered by the contract. ${ }^{40}$

${ }^{23}$ Shepard v. Lesser, I27 Ark. 590, I93 S. W. 262 (I917); Clemens v. Meadows, $23 \mathrm{Ky}$. I78, 94 S. W. I3 (I906); Oliver v. Gilmore, 52 Fed. 562 (C. C. Mass., I892); Cravens v. Carter Crune Co., 92 Fed. 479 (C. C. A. 6th, I899); Cleaver v. Lenhart, I82 Pa. 290, 37 At1. 8II (I897) (a contract not to compete made by the seller after the sale was completed, held invalid); Mitchell v. Reynolds, supra note 9.

${ }^{5}$ Taft, J., in United States v. Addyston Pipe and Steel Co., 85 Fed, 271 , 288 (C. C. A. 6th, 1898).

${ }^{40}$ This question is interestingly presented by Gamewell Fire Alarm Tel. Co. v. Crane, 160 Mass. 50, 35 N. E. 98, 22 L. R. A. 673 (1893). Crane, who had manufactured fire-alarm and police telegraph apparatus for twelve years for the plaintiff, and who had no other customer, sold out his business to the plaintiff and agreed not to engage in the business of manufacturing or selling fire alarm or police telegraph apparatus, and not to enter into competition with the plaintiff for ten years. Crane sold no goodwill to the defendant and was not therefore, by entering into a competing business, encroaching upon any goodwill he had sold to the plaintiff; and the court felt that the stipulation was "something more than is reasonably necessary to protect the plaintiff in the enjoyment of the property it bought." If goodwill were all the plaintiff bought this reasoning of the court would be unobjectionable. But there was property 
If the contract imposes a burden upon the promisor out of all relation to the benefit to the promisee, it will be held to be unreasonable. ${ }^{41}$ The degree of restraint which should be decreed to be reasonable should vary with the interest of the covenantee which it seeks to protect. In the sale of a business the interest of the covenantee which is sought to be protected is very different from the interests of the employer covenantee in a covenant not to compete after a term of employment. In the former case the social interest sought to be protected is making the goodwill of a business which a man has built up, and which is valuable, a legitimate and vendible asset. To hold invalid the contract of the vendor not to compete, where unrestrained competition will effectively diminish the value of the goodwill sold, would prevent goodwill from being adequately transferred. The balance of social interest favors allowing a man freedom to restrain himself from carrying on a particular business in order that he may be able to sell a valuable business asset which he has developed. The extent to which the seller may restrain himself from carrying on the trade or business will depend on how far such restraint is necessary to prevent interference with the goodwill sold. Whether the restraint may be general or universal in extent should depend on whether the goodwill of the business sold requires an unlimited restraint for its reasonable protection. The mere fact that the covenant is unlimited in time and space ought never to make it void, and the cases which hold covenants void on that ground alone have no sufficient reason to support them.

In the case of a covenant not to engage in competing trade after the termination of an employment, the interest of the covenantee which is sought to be protected is the interest which society has that professional and business men be protected in employing efficient assistants. To protect this interest is for the benefit of not only employers but of employees as well, enabling the latter to dispose of their services advantageously. In order

sold, and it was a type of property that might not be vendible to any great extent unless the vendor was able to preclude himself from entering into the same business or competing with the buyer; and this covenant might very well have been found to be ancillary to an interest purchased by the buyer, the failure to enforce which would impair the interest bought.

"See infra notes 75 and 94. 
that this interest may be protected, employees should be able to legally bind themselves not to use the personal knowledge of trade secrets and the personal influence with customers of the employer which the employee gains in the employment. There is no basis, however, for holding that the contract not to compete should be treated as valid when the restraint extends beyond the use of such knowledge and influence. Cases assuming that covenants which do not go beyond giving the protection which the employer's business requires are valid ${ }^{42}$ go too far, as the employer's business may require restraints which he is not entitled to impose.

Covenants in restraint of trade may include covenants not to compete which are ancillary (I) to the sale or lease of a business, (2) to the sale or lease of property, (3) to a contract of partnership or retirement from a partnership, and (4) to contracts of a servant or agent entering employment. Mr. Justice Taft, then Circuit Judge, in United States v. Addyston Pipe \& Steel Co. ${ }^{43}$ summarized such of these contracts as might be upheld as follows:

"Covenants in partial restraint of trade are generally upheld as valid when they are agreements (I) by the seller of property or business not to compete with the buyer in such a way as to derogate from the value of the property or business sold; (2) by a retiring partner not to compete with the firm; (3) by a partner pending the partnership not to do anything to interfere, by competition or otherwise, with the business of the firm; (4) by the buyer of property not to use the same in competition with the business retained by the seller; and (5) by an assistant, servant, or agent not to compete with his master or employer after the expiration of his time of service. Before such agreements are upheld, however, the court must find that the restraints attempted thereby are reasonably necessary ( $I, 2$, and 3 ) to the enjoyment by the buyer of the property, goodwill, or interest in the partnership bought; or (4) to the legitimate ends of the existing partnership; or (5) to the prevention of possible injury to the business of the seller from use by the buyer of the thing sold; or (6) to the protection from the danger of loss to the employer's business caused by the unjust use on the part of the employee of the confidential knowledge acquired in such business."

"Herbert Morris v. Saxelby, [I916] A. C. 688.

${ }^{13}$ Supra note 39. 


\section{- Contracts Not to Compete on the Sale of a Business}

(a) How far the sale of a goodwill without a covenant not to compete restricts competition. The sale of a business carries with it the goodwill of the business, although not expressly mentioned; $;^{44}$ and a sale of the goodwill, whether expressly mentioned or implied, on the sale of the business generally precludes the seller from soliciting the former customers of the business sold. It was once held in England ${ }^{45}$ that the vendor of a business (partnership in the particular instance) might not only compete with the buyer but might solicit trade from customers of the old firm; but the House of Lords in 1895 in Trego v. Hunt ${ }^{46}$ overruled the earlier case, and Trego $v$. Hunt has been followed in England ${ }^{47}$ and in most of the American states, with the result that the law now generally is that the seller of a business, although he has made no covenant of any kind, may. not solicit the former customers of the business. ${ }^{48}$ In a few states, however, the sale of a business does not preclude the seller from soliciting the customers

4 In Louisiana goodwill must be expressly included. Menendez ₹. Holt, I28 U. S. 514 (I888). See also note in I917 Ann. Cas. I0r5, 5 L. R. A. (N. S.) I077, 16 I. R. A. (N. S.) 240 .

Smith v. Webb, I76 Ala. 596, 58 So. 9I3 (IgI2); Didlake v. Roden Grocery Co., I60 Ala 484, 49 So. 384 (rgog); Shafer v. Sloan, 3 Cal. App. 335, 85 Pac. I62 (Ig06); Acme Harvester Co. V. Craver, 209 Ill. 483 , 70 N. E. 1047 (1904); Bennett v. Carmichael Produce Co., 64 Ind. App. 341 , II5 N. E. 793 (I9I7) ; Wilmer v. Thomas, 74 Md. 485, 22 Atl. 403 (I89r); Fairfield v. Lowery, 207 Mass. 352, 93 N. E. 598 (IgII); Hoxie v. Chaney, I43 Mass. 592, Io N. E. 7I3 (1887); William v. Farrand, 88 Mich. 473, 50 N. W. 446 (189I); Johnson v. Bruzek, I42 Minn. 454, 172 N. W. 700 (1919); Merry v. Hoopes, III N. Y. 4I5, I8 N. E. 7 I4 (I888); Hegeman v. Hegeman, 8 Daly I (N. Y. I880); Little v. Fleischman, I77. N. C. 2I, 98 S. E. 455 (I9I9).

4 Pearson v. Pearson, 27 Ch. D. 145 (1884).

[18g6] A. C. 7 .

"Jennings v. Jennings, [I8g8] I Ch. 378; Gillingham v. Beddow, [Ig00] 2 Ch. 242; Carl v. Webster, [I904] I Ch. 685.

" In England, see supra notes 46 and 47 ; in the United States, Ranft v. Reimers, 200 I11. 386, 65 N. E. 720 (1902); Drake v. Dodsworth, 4 Kan. 159 (I867) ; Fairfield v. Lowry, 2I7 Mass. 352, 3 N. E. 598 (IgII); Brown v. Benzinger, I18 Md. 29, 84 Atl. 79 (I912) ; Finch v. Michael, I67 N. C. 233, 83 S. E. 458 (1914) ; Faust v. Rohr, 166 N. C. 187, 81 S. E. 1096 (I9I4); Auto Hearse Mfg. Co. v. Bateman, Iog Atl. 735 (N. J. 1920) ; Hilton v. Hilton, 89 N. J. Eq. 182, I04 Atl. 375 (I918) ; Snyder Pasteurized Milk Co. v. Burton, 85 N. J. Eq., 185, 83 Atl. 907 (1912) ; Von Bremen v. MacMonnies, 200 N. Y. 4I, 93 N. E. 186 (1910): Wentzel v. Barbin, 189 Pa. 502, 42 Atl. 44 (I899); Ferris v. Pett, 42 R. I. 48, 105 Atl. 369 (I9r9); Zanturjian v. Boornazian, 25 R. I I5I, 55 Atl. I99 (I903) ; Sheehan v. Sheehan-Hackley, I96 S. W. 665 (Tex. Civ: App., 1917). 
of the old business, where there is no agreement not to compete. ${ }^{49}$ But the sale of a business does not preclude the vendor who has not covenanted not to compete from setting up a rival and competing business, if he does not solicit the old customers. ${ }^{50}$ Massachusetts is an exception, it being held there that a sale of the goodwill of the business even without a covenant not to compete may in some cases preclude the setting up of a competing business. ${ }^{51}$

(b) How far competition may be restricted by a covenant not to compete. The covenant in restraint of trade accompanying the sale of property or business may be made either by the buyer or seller. The seller may agree not to set up in competition with the buyer, or the buyer may agree not to use the property or the business purchased in competition with property or business retained by the seller. The same rules for determining the reasonableness or the validity of the covenant should apply whether the covenant is made by the seller or the buyer.

A contract not to compete which is not ancillary to the sale

6ottrell v. Babcock Printing Press Mfg. Co, 54 Conn. 122, 6 Atl. 79r (I886); Williams v. Farrand, 88 Mich. 473, 50 N. W. 446 (I89r); Fish Bros. Wagon Co. v. LaBelle Wagon Works, 82 Wis. 546,52 N. W. 595, r6 L. R. A. 453 ( I892). An agreement not to compete may be implied; see Lazan v. Berg, 179 Wis. 6Io, I9I N. W. 966 (Ig23).

${ }^{50}$ Didlake v. Roden Grocery Co., supra note 44; Howard v. Taylor, 90 Ala. 247, 8 So. 36 (189o) ; Cottrell v. Babcock Printing Press Mfg. Co., supra note 49; Porter v. Gorman, $65 \mathrm{Ga}$. II (I879) ; Ranft v, Reimers, sispra note 48; Beatty v. Coble, I42 Ind. 329, 4I N. E. 590 (1895); Dare v. Foy, I8o Iowa, II 56, I64 N. W. I79 (I9I7) ; Drake v. Dodsworth, 4 Kan. I59 (I867); Bergamini v. Bastian, 35 La. Ann. 6o (1883); Hutchinson v. Nay, I87 Mass. 262, 72 N. E. 974 (1904); Williams v. Farrand, 88 Mich. 473, 50 N. W. 446 (189I); Counts v. Medley, 63 Mo. App. 546, 146 S. W. 465 (1912); Wessel v. Havens, 9r Neb. 426,136 N. W. 70 (I912); Faust v. Rohr, I66 N. C. 187, 8I S. E 1096 (1914); Morehead Sea Food Co. v. Way, 169 N. C. 679,86 S. E. 603 (r915); Scudder v. Kilfoil, 57 N. J. Eq. I7I, 40 Atl. 602 (I898); Althen v. Vreeland, 36 Atl. 479 (N. J. 1897); Von Bremen v. MacMonnies, 200 N. Y. 4I, 93 N. E. I86 mod. I38 App. Div. 3I9, I22 N. Y. Supp. I087 (1910) ; Brass, etc., Works v. Payne, 50 Ohio St. Ir5, 33 N. E. 88, (I893); see Neutzel v. Barbin, 189 Pa. 502, 42 Atl. 44 (1899) ; White v. Trowbridge, 216 Pa. II, 64 Atl. 862 (I906); Zanturjian v. Boornazian, 25 R. I. I5I, 55 Atl. Ig9 (I903); Fine v. Iawless, I39 Tenn. I60, 201 S. W. I60 (I9I8); Sheehan v. Sheehan-Hackley, I96 S. W. 665 (Tex. Civ. App. I917).

"Angier v. Webber, I4 Allen 2 II (Mass. I867) ; Foss v. Roby, I95 Mass. 292, 8I N. E. 199 (I907); Old Corner Book Store v. Upham, I94 Mass. Ior, 80 N. E. 28 (I907); Gordin v. Knott, I99 Mass. I73, 85 N. E. 4 I7 (I908); Bachelder v. Bachelder, 220 Mass. 43, I07 N. E. 455 (I9I4). See Webster v. Webster, I80 Mass. 316, 62 N. E. 383 (1903), where the sale was of goods and chattels, and no goodwill was sold. Also Hoxie v. Chaney, I43 Mass. 592, Io N. E. 7r3 (I887). 
of a business or some lawful contract is not valid. ${ }^{52}$ Thus it was held in Tuscaloosa Ice Mfg. Co. v. Williams, ${ }^{53}$ where the plaintiff and defendant each owned and operated the only ice plants in a small city, and the plaintiff agreed for a consideration not to run his ice plant for five years, that the contract was invalid. In Arctic Ice Co. $v$. Franklin Ice $C_{0 .}{ }^{54}$ an agreement by one ice company to sell all its output to a second, which should discontinue manufacturing ice and only sell the ice of the first company, was also held invalid. In Clemons v. Meadowes ${ }^{55}$ the New Meadows Hotel agreed to close up and remain closed for three years in consideration of the Usona Hotel, a competing hotel in a city of 5000 inhabitants, paying the Meadows Hotel \$roo.00 per month. The court held this contract was invalid, as it was not a restraint imposed to protect a business sold, but merely a means used to eliminate a competitor. And in Oliver.v. Gilmore, ${ }^{56}$ where Oliver Bros. agreed with eight corporations to close their works for a period of five years in consideration of the corporations paying

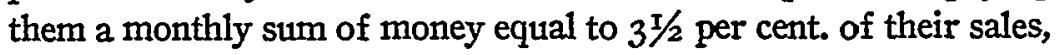
the court held the contract invalid as in unreasonable restraint of trade, it not being ancillary to the sale of a business.

The restraint, to be reasonable, must not be larger than is required for the necessary protection of the promisee. In Oregon Steam Navigation Co. v. Winsor, ${ }^{57}$ the California Navigation Co. sold the steamer, New $W$ orld, to the plaintiff, the latter agreeing not to use the steamer in the waters of California for ten years. The plaintiff sold the steamer to the defendant Winsor in 1864 with a stipulation that the defendant would not run the vessel in the waters of California or on the Columbia River for ro years from I867. The covenant was broader than was necessary to

Mitchel v. Reynolds, supra note 9; United States v. Addyston Pipe \& Steel Co., supra note 39. The covenant may protect the buyer in the use of a particular piece of property purchased: Mar Hof Co., Inc. $\nabla$. Rosenbacher, 176 N. C. 330, 97 S. E. 169 (1918); New York Bank Note Mfg. Co. v. Kidder Press Mfg. Co., 192 Mass. 403, 78 N.' E. 463 (I906); Blauner v. Williams Co., 36 Misc. 173, 73 N. Y. Supp 165 (1901).

I27 Ala, Iro, 28 So. 669 (Ig00).

st I45 Ky. 32, I39 S. W. 1080 (I9II).

${ }^{\mathrm{t}}$ I23 Ky. 178, 94 S. W. I3 (1906).

${ }^{56} 52$ Fed. 562 (C. C. Mass., I89z).

${ }^{87} 20$ Wall. 64 (U: S., 1873). 
protect the plaintiff as respects the use of the waters of California, as he was only entitled to a protection for Io years from I864; and the court held the contract valid for Io years as to the Columbia River and for seven years as to Cálifornia. In Hodge $v$. Sloan ${ }^{58}$ the plaintiff conveyed land to John D. Sloan and Sloan in turn to the defendant. Sloan covenanted not to sell any sand off the land, and the defendant had notice of this covenant. The plaintiff had a well-established business selling sand and the vendee did not want the land for that purpose. The plaintiff had declined to sell the land for fear such sale would injure his business and deprive him of his living, but was willing to make the sale upon the purchaser making a covenant not to sell sand off the land purchased. The court held that this covenant was valid and binding upon the defendant. It is interesting to compare this case with Brewer $v$. Marshall and Cheeseman, ${ }^{59}$ where the vendor covenanted not to sell any marl off the premises adjoining the premises conveyed, and the defendant was a purchaser from the vendor with notice of the covenant. The court held the covenant was invalid as an unreasonable restraint of trade in that it imposed a greater restriction than necessary for the protection of the vendee. In both of these cases, the restraint was general as to time, place and person, and if the restriction was placed upon the power of the vendor to sell in order to protect the purchaser in selling marl from land which he bought for that purpose, there would seem to be no ground for distinguishing the cases. The restraint in each case is no more general than is reasonably required to protect the covenantee in the property retained or conveyed. In Henschke v. Moore, ${ }^{60}$ plaintiffs granted to defendants the exclusive right to manufacture and use a patented apparatus for feeding horse-hair from a bundle to a wrapping device, the contract containing a provision for surrender or cancellation of the license, and that in case of such surrender or cancellation the defendant would not, either directly or indirectly, engage in the business of manufacturing or selling horse-hair yarn similar to

\footnotetext{
107 N. Y. 244, 17 N. E. 335 (1887).

50 I9 N. J. Eq. 537 (1868).

${ }^{\infty} 257 \mathrm{~Pa}$. 3 $\div$, , ror At1. 308 (1917).
} 
the product of the machine. The court held that while the plaintiff was entitled to require a covenant for a proper protection of his use of the machine, this restraint was unreasonable and not legitimate, as going beyond what was needed to protect the plaintiff. It said: "There was nothing to justify them in seeking to restrain defendants from engaging in the business of manufacturing hair yarn by the use of any machine which did not infringe their patent."

The case of Wittenberg $v$. Mollyneaux ${ }^{61}$ involves an interesting application of the principle that covenants not to carry on business or not to compete are valid where merely ancillary to the sale of property, business, or a term of employment. In this case the plaintiff owned an hotel in Sutton which he agreed to exchange for the defendant's hotel. The deed to the defendant provided that the premises therein described should not be used for hotel purposes for two years. This stipulation was violated and suit brought upon the covenant, and it is alleged in the defense that the stipulation is invalid, as a restraint of trade tending to a monopoly, there being but two hotels in Sutton. The court held the covenant valid, saying that although such agreements tend to suppress competition and to make for monopolies, they are valid and in harmony with the policy of the state (to promote commerce by facilitating the transfer of property) if they were made for such purpose; but that if the main purpose of the transaction was to secure a monopoly, and the transfer of the property was merely an incident or a means to that end, it was bad as a restraint on trade. The fact that the hotel which the covenantee obtained was not and had not been running for some time whereas the hotel which he transferred had been operating, makes the situation one in which the covenantee is merely requiring the covenantor, who has sold him an hotel and an hotel business, not to set up an hotel business in competition with him. The covenantee has purchased an hotel and a business, the protection of which requires this covenant on the part of the seller.

Not infrequently it is difficult to discover whether the agreement not to compete is the main thing, to which the sale of a busi-

60 Neb. 583,83 N. W. 842 (Ig00). 
ness is ancillary, or whether the agreement not to compete is ancillary to a bona fide sale. The fact that the agreement contains nothing more than a covenant not to compete does not necessarily mean that the covenant is not ancillary to a sale. In Cincinnati, Portsmouth, Big Sandy \& Pomeroy Packet Co. v. Bay, ${ }^{62}$ where the plaintiff sold to the defendant some steamers, barges, coal flats, and stock, and agreed not to engage in the freight and passenger packet business, it was contended by the defendant that the contract was illegal as an illegal restraint upon trade, the contract not to carry on the business not being ancillary to the sale of a business, for there was no business sold. To this contention Mr. Justice Holmes replied: "It is said there is no sale of goodwill. But the covenant makes the sale. Presumably all that there was to sell, besides certain instruments of competition, was the competition itself, and the purchasers did not want the vendors' names." In National Benefit Co. v. Union Hospital Co. ${ }^{63}$ the plaintiff agreed with the defendant not to sell insurance in Minnesota, Wisconsin and the northern peninsula of Michigan (with certain exceptions) for three years, the defendant agreeing to pay plaintiff a stipulated sum for refraining from engaging in the business. The court held this contract constituted a sale of the plaintiff's business and goodwill, and was valid. In Wickins $v$. Evans ${ }^{64}$ three persons engaged in manufacturing and selling boxes and trunks in England and Wales entered into a contract to divide the country into three parts, each taking a part to the exclusion of the others. The court held this contract valid.

If there is no goodwill yet developed in a business, as in Gamewell Fire Alarm Co. v. Crane, ${ }^{65}$ where the seller had manufactured police telegraph apparatus exclusively for the buyer for twelve years, a covenant by the seller on making a sale of the business to the buyer not to compete would not be ancillary to or protect a goodwill sold, and it would therefore be invalid. Sometimes courts have failed to observe this restriction, that a contract not to compete, to be valid, must be ancillary to the sale of prop-

${ }^{62} 200$ U. S. I79 (I906).

${ }^{03} 45$ Minn. 272, 47 N. W. 806 (I89I).

of 3 Younge \& J. 318 ( 1829 ).

- Supra note 40 . 
erty, business goodwill, or a term of employment. Thus in Leslie $v$. Lorillard ${ }^{68}$ there was no sale of any tangible property whose value to the buyers might be impaired without the covenant not to compete; and there does not seem to have been any substantial goodwill developed by the seller. The court in its discussion of the covenant does not seem to think its validity depends upon it being ancillary to the sale of a business goodwill or any main transaction. A similar ignoring of this requirement is exhibited in Kellogg $v$. Larkin, ${ }^{67}$ where the mill owners of Milwaukee agreed to pay to the warehouse men four cents per bushel on wheat coming into the Milwaukee market, so far as they were able to control the same; and the warehousemen agreed "not to purchase, store, or handle any wheat in the Milwaukee market except under the direction of the defendants from the seventh of January to the first day of August following." The court held this covenant valid, as it was not general, and was useful to the promisees as a protection to them in the prosecution of their business. The covenants accompanied leases, but it was obvious that the covenants were not in any proper sense property leased. The leases were made simply as a part of the scheme to restrain trade or reduce competition, and were merely ancillary to such purpose.

In Palumbo v. Piccioni ${ }^{68}$ it was held that a proprietor of a shoe repairing business who had bought out a competitor under an agreement by the seller not to engage in that business in the city for five years, could restrain such seller from engaging in the business within the city within that time even after he had resold the business purchased. The court reasoned that the contract could be sustained, as it was for the benefit of the complainant's other business as well as the business he purchased of the defendant. The court completely failed to grasp the theory upon which contracts not to compete are upheld. In the case of a contract not to compete which is ancillary to the sale of a business the contract is upheld, if at all, upon the principle that the social interest in not having the promisor divested of his means of earn-.

${ }^{\text {es }}$ I1o N. Y. 519, 18 N. E. 363 (1888).

" 3 Pinney I23, 3 Chandler I33 (Wis. $185 \mathrm{I}$ ).

$\infty 89$ N. J. Eq. 40, 103 Atl. 8r5 (19r8). 
ing a livelihood and of supporting himself and family, and the community deprived of the benefit of his competition, are of less importance than the social interest involved in making a business, which the seller has built up, advantagecusly vendible. The covenant not to compete if made exclusively for the benefit of the complainant's other business would certainly not be upheld; and it seems clear that to permit the complainant to enjoin the seller after he has parted with the business purchased in order to protect his other business is unwarranted. If the person who purchased the business of the complainant bought such property understanding that he was getting it free from the possibility of the defendant's competition, he could have the defendant restrained ${ }^{69}$ because the covenant is incident to the sale of the business, and the benefit runs with it. But unless the complainant in making the sale had undertaken to provide against the competition of the defendant, he has no interest to protect after he has sold the business which would warrant the issuance of an injunction at his behest.70

Often the covenant not to compete is made to appear as ancillary to a sale of a business when the sale is merely a pretense, ${ }^{71}$ as in Clark v. Needham, ${ }^{72}$ where the plaintiffs agreed, in consideration of \$I500 to be paid annually, to lease their machinery for five years and not to manufacture or sell chaplets for that period. The court held this contract invalid, as the lease was a mere pretense, and the covenant not to manufacture or sell was not made to protect a business bona fide leased or sold. If there is a bona fide sale of a business, a covenant not to compete in protection of the business purchased has been held not invalid where no monopoly resulted, although the purpose of the transaction was to eliminate the seller as a competitor. ${ }^{73}$

Sickles v. Lauman, I85 Iowa 37, I69 N. W. 670 (I918) ; Hickey v. Brinkley, 88 Neb. 356, I29 N. W. 553 (I9II) ; Scherman v. Stern, 93 N. J. Eq. 626, II7 Atl. 631 (I922) ; Jochum Bros., Inc., v. Ridgewood Pie Baking Co., 206 N. Y. Supp. 252 (I924).

${ }^{30}$ See Oregon Steam Navigation Co. v. Winsor, supra note 57. (1890)

${ }^{71}$ Western Wooden Ware Ass'n. v. Starkey, 84 Mich. 76, 47 N. W. 604

${ }^{72}$ 125 Mich. 84, 83 N. W. 1057 (1900).

${ }^{73}$ United States Chemical Co. v. Provident Chemical Co., supra note 32. 
In the sale of a professional business there may be no tangible property to transfer, and in such case, where there exists a goodwill to be sold, a covenant not to carry on the practice of the profession throughout the region to which it had extended would merely be a means of selling the goodwill. ${ }^{74}$

Even a covenant which is ancillary to the sale of a business will be void unless it is essential to the protection of some legitimate interest acquired by the buyer under the sale. If the restraint, no matter how narrow, is broader than is required to protect the thing purchased, the covenant will be bad. ${ }^{75}$ But a covenant no broader than is needed to protect the goodwill of a business sold is valid ${ }^{78}$ except where the restraint is general and the case arises in one of those jurisdictions which still adhere to the rule that general restraints are always bad èven though they are reasonable. On principle, barring the question of monopoly, the covenant not to compete made by the vendor in connection with the sale of a business may validly extend the restraint over such territory and for such length of time as is required to give the purchaser the full benefit of his purchase, no matter if the restraint is unlimited in extent both in space and time; but any restraint beyond such limit is unreasonable and void. This is the English law ${ }^{77}$ and is fast becoming the American law. ${ }^{78}$ The exceptions still existing in America are in those jurisdictions where the restraint if unlimited territorially ${ }^{79}$ is treated as bad, or where the restraint covers the whole of a state ${ }^{80}$ or the United States. ${ }^{81}$

- There is some conflict in the cases as to whether the seller may make a covenant not to compete broader than the existing business sold. Some courts limit the possibility of a valid cove-

\footnotetext{
"Rowe v. Toon, 185 Iowa 848, I69 N. W. 38 (1918).

${ }^{75}$ Wyder v. Milhomme, 96 N. J. L. 500, II5 Atl. 380 (I92I).

${ }^{18}$ McClurg's Appeal, $58 \mathrm{~Pa}$. 51 (1868); Rowe v. Toone, I85 Iowa 848, I69 N. W. 38 (I9I8).

"See cases cited in notes 15,16 supra.

${ }^{73}$ See supra notes 28, 29, 32, 33.

'See supra note 3I.

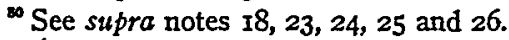

"See sipra note 3 I.
} 
nant to the extent of the existing business. ${ }^{82}$ Others would allow the covenant to cover territory wherever "by reasonable attention the trade could be expected to extend." 83 Thus in Hall Mfg. Co. v. Western Steel \& Iron Works, ${ }^{84}$ where the existing business extended over thirty-four states and two Canadian provinces, and could by reasonable attention be expected to extend throughout the United States and Canada, a covenant not to engage in the business unlimited in extent was sustained.

\section{Contracts Not to Compete After a Term of Employment}

Contracts by an employe not to compete with his employer during the term of employment are not dealt with here. They involve entirely different considerations from a contract not to compete after a term of employment. The former are never treated as illegal restraints of trade, ${ }^{85}$ yet equity refuses to enforce these negative covenants not to work for another than the employer during the term unless the services are of a peculiar or unique character. ${ }^{86}$

82 Trenton Potteries Co. v. Olyphant, 58 N. J. Eq. 507, 43 Atl. 723, 46 L. R. A. 255 (1899). The court says: "Appellant contends that such contracts were zeasonably required to protect it, not only in the areas in which the business it purchased of respondents had been carried on, but also in other states to which it might extend that business. But this contention I deem to be inadmissible."

${ }^{83}$ Wyder v. Milhomme, supra note 75 . Covenant held too extensive, as it covered a "territory many times larger than the actual or reasonably expected fields of operations of the covenantee." See also Kochenrath v. Christman, I80 Ky. 799, 203 S. W. 738 (1918).

227 Fed. 588 (C. C. A., 7th, 1915).

${ }^{85}$ A contract by an employee not to compete with the employer during the term of employment is never objectionable as in restraint of trade. In Corning v. Carr, I67 Mass. 548, 46 N. E. II7 (1897), a contract by defendant to employ the plaintiff if he would give up his business and enter the defendant's service in the same occupation, it was held that although it restrained the plairtiff from engaging in business, it was not in restraint of trade, as the restraint was only to continue while the plaintiff was in the defendant's employment. See also Harrison v. Glucose Sugar Refining Co., II6 Fed. 304 (C. C. A. 7th, I902); Knapp v. S. Jarvis Adams Co., supra note 32; Bossert v. S. Jarvis Adams Co., I35 Fed. I0I5 (C. C. A. 6th, I905); Robinson \& Co. v. Heuer [I898] 2 Ch. 455 .

In the following cases injunctions were issued on a showing that the services were unique: Lumley v. Wagner, I De G. M. \& G. 604 (Eng. I852); Kieth v. Kellermann, 169 Fed. I96 (C. C. S. D. N. Y., 1909); Comstock v. Lopokowa, I90 Fed. 599 (C. C. S. D. N. Y., IgIr); Tribune Asso. v. Simonds, I04 Atl. 386 (N. J. I9I8); S. C. Posner Co. v. Jackson, 223 N. Y. 325, II9 N. E. 573 (I918); Daly v. Smith, 6 Jones \& S. 158 (N. Y., I874). In the following the injunction was refused because the services were not unique: Burney $v$. Ryle, 9I Ga. 70I, I7 S. E. 986 (1893) ; Rosenstein v. Zentz, II8 Md. 564, 85 Atl. 
With respect to contracts not to compete after a term of employment, the objection that the services are not unique or peculiar does not prevail in equity; but the question of difficulty is whether the contract constitutes an illegal restraint of trade. The disposition of courts to be more reluctant to sustain agreements which form part of a contract of employment than to sustain similar agreements attached to a sale has been criticised, and it has been asserted that no distinction should exist between the two. ${ }^{87}$ Thus in Eureka Laundry Co. v. Long $^{88}$ the court asks:

"Does it make any substantial difference whether the thing of a value bargained for is contained in a contract of sale, or in a contract of hiring? If it is lawful and proper to protect a business just about to be acquired from certain acts by the seller, who is familiar with such business, why is it not equally lawful and proper to protect an established business from such acts by one who has become familiar therewith? We perceive no difference in principle. The purchaser says to the seller: 'You are familiar with this business. You know your customers; your personal acquaintance with them is such that you could divert their trade from me if you saw fit. Now, I will purchase your business upon the express condition that you will agree for a limited length of time not to engage in a like business in this locality; at the expiration of that time I shall know my business and my customers well enough to be able to protect myself.' So the owner of an established business says to a prospective employe: 'In the employment, you will become familiar with the customers of my business in a way that I cannot; you will meet them frequently, while $I$ see them rarely, if ever. Now, I will hire you upon the express condition that you will agree for a limited length of time not to solicit trade from such of my customers as you may have supplied while in my employ, and will not engage in my business within a limited

675 (19r2) ; W. J. Johnson Co. v. Hunt, I42 N. Y. 621, 37 N E. 564 (I894); Geo. A. Kessler \& Co. v. Chappelle, 73 App. Div. 477, 77 N. Y. Supp. 285 (1902); Hammerstein v. Mann, I37 App. Div. 580, 122 N. Y. Supp. 276 (1910); Cort v. Lassard, 18 Or. 221, 22 Pac. ro54 (1889); Columbia College v. Tunberg, 64 Wash. 19, II6 Pac. 280 (I9Ir) ; Chain Belt Co. v. Von Spreckelsen, II7 Wis. I06, 94 N. W. 78 (1903).

"WIIliston, Contracts, § 1643: ". . . the distinction . . . seems inadvisable as a positive rule of law. . . The ultimate question should be the same in both cases."

${ }^{*} 146$ Wis. 205, I3I N. W. 412 (Igiri). 
time, in the territory you have occupied; at the end of that time my new employes will be sufficiently well acquainted with my customers to protect my business.' Why is not one contract as valid as the other?"

It is admitted that the objections to the validity of the contract, namely, the divestment by the promisor of the means of earning a livelihood and of supporting himself and family, and the deprivation of the community of the benefit of his services and competition, are more likely truly to exist in the case of the employee than in the case of the seller of a business, since the employee from whom such a covenant is exacted is more likely to be an expert with little knowledge or skill in other kinds of work than is an ordinary seller. But it is urged that this difference in the weight of the objections is not sufficient to differentiate the cases. ${ }^{89}$ This assumption, that the distinction, if any, must rest in the difference in the objectionable nature of the restraints imposed, ignores an important difference in the nature of the interests sought to be protected and for the protection of which the restraint is imposed.

The interests which promises ancillary to a term of employment are appropriate to protect are much more restricted than are the interests which promises made in connection with a sale protect. It is submitted that this difference in the nature of the interests involved justifies the position which the majority of courts take in being "less disposed to sustain an agreement which forms part of a contract of employment" 90 than where it is part of a sale. It is true that the promises in each case may facilitate a sale in the one, that of a business, and in the other, that of services;

WIIIISToN, loc. cit. supra: "Courts are less disposed to sustain an agreement which forms part of a contract of employment to refrain from subsequently engaging in competitive occupation than where a similar agreement is attached to a contract of sale. There is likely to be greater hardship to the promisor and therefore injury to the public in the former case, as for instance where an employee, expert in a narrow and technical specialty, engages not to practice his specialty. The distinction, however, seems unadvisable as a positive rule of law. If it is rightful to protect a business when it is purchased it should be lawful to protect an established business from injury by an employee, unless circumstances of great hardship exist. The ultimate question should be the same in both cases, what is necessary for the protection of the promisee's rights and is not injurious to the public."

${ }^{20}$ Supra note 89. 
and that there is a strong public policy favoring facility of transfer of such interests. But the promise in the one case serves a purpose distinct from that served in the other. In the sale of a business the promise not to compete, and its performance, may be necessary to secure an adequate delivery to the purchaser of the thing sold; but not so in the sale of services. The services are completely delivered without the aid of any restraint on the promisor after he leaves the employment. The promise not to compete is not made to protect the thing transferred, but to protect the employer from damage being done to that which he already has, by reason of the employee's peculiar opportunity afforded by the employment of accomplishing such injury. More specifically, the employer is entitled to be free from having his customers deflected or his trade secrets exposed or used by others by reason of the acquaintanceship with them which the employee has gained through his employment. It is reasonably clear on principle that the employer can gain no added power of restraint over the employee by virtue of the employment, but can only protect his business from the inroads which the confidential relationship enables the employee to make. There are dicta and decisions which observe this distinction between promises ancillary to a sale and those ancillary to a term of employment, and carefully define the extent of restraint possible in the latter case. In Morris $v$. Saxelby, ${ }^{91}$ where there was little or no evidence that the defendant employee ever came in contact with the plaintiff's customers or was ever entrusted with trade secrets, a covenant by the employee, providing that he would not "during a period of seven years from the date of his ceasing to be employed by the company . . . either in Great Britain or Ireland" engage in the business which his employer carried on, was held invalid. The court after discussing the case of the sale of the goodwill of a business said:

"It is quite different in the case of an employer taking such a covenant from his employee or apprentice. The goodwill of his business is, under the conditions in which we live, necessarily subject to the competition of all persons (includ-

\footnotetext{
' 92 [Igr6] A. C. 688.
} 
ing the servant or apprentice) who choose to engage in a similar trade. The employer in such a case is not endeavoring to protect what he has, but to gain a special advantage which he could not otherwise secure. I cannot find any case in which such a covenant against competition by a servant or apprentice has, as such, ever been upheld by the court. Wherever such covenants have been upheld it has been on the ground not that the servant or apprentice would by reason of his employment or training obtain the skill and knowledge necessary to equip him as a possible competitor in the trade, but that he might obtain such personal knowledge of and influence over the customers of his employer, or such an acqaintance with his employer's trade secrets, as would enable him, if competition were allowed, to take advantage of his employer's trade connection or utilize information confidentially obtained." ${ }^{82}$

If the restraint is no more than is reasonably necessary to protect the employer against the deflection of customers or misuse of trade secrets by the employee through the opportunity which his employment has given him, the courts uniformly uphold the covenant $^{93}$ and give relief either at law or in equity. But the

${ }^{22}$ Supra note 9r, at 709. The court notes that in W. C. Leng \& Co. v. Andrews [Ig09] I Ch. 763 , a covenant by a newspaper reporter who did not come in contact with the covenantee's customers, not to engage in the work of a reporter in a limited area, was held invalid; and it then proceeds; "In Mason v. Provident Clothing and Supply Co., [I9I3] A. C. 724, it was argued, apparently for the first time in this class of case, that an employer might reasonably say, 'I will not have the skill and knowledge acquired in my employment imparted to my trade rivals,' and that the validity of the restraint did not depend upon personal contact with the employer's customers, but upon the fact that the employe gained that general knowledge which put him into a position to compete with his master and made him a source of danger, against which the master was entitled to protect himself. This argument was rejected by your Lordships' House, and the restraint in question was held bad, as being wider than was necessary to protect the employer from injury by misuse of the employe's acquaintance with customers or knowledge of trade secrets."

${ }^{93}$ Hulse v. Bonsack Mach. Co., 65 Fed. 864 (C. C. A. 4th, I895) ; Carter v. Alling, Knapp v. S. Jarvis Adams Co., both supra note 32 ; Bossert v. Lane, I35 Fed. Ior5 (C. C. A. 6th, I905); Freudenthal v. Espey, 45 Colo. 488, 102 Pac. 280 (I909); Styles v. Lyon, 87 Conn. 28, 86 Atl. 564 (1913); Am. Ice Co. v. Lynch, 74 N. J. Eq. 298, 70 At1. I38 (I908); Owl Laundry Co. v. Banks, 83 N. J. Eq. 230, 89 At1. I055 (I9I4); Golden Cruller \& Doughnut Co. v. Masher, I23 Atl. I50 (N. J., I923) ; Sarco Co. v. Gulliver, 129 Atl. 399 (N. J., I925); Eastern N. Y. Wet Wash Laundry Co. v. Abrahams, I73 App. Div. 788, I60 N. Y. Supp. 69 (1916); Clark Paper \& Mfg. Co. v. Stenacker, roo Misc. I73, 165 N. Y. Supp. 367 (I9I7) ; A. Finkenberg's Sorf v. Adest, 203 App. Div. 631, I97 N. Y. Supp. 246 (I922); New York Linen Supply \& Laundry Co. Schachter, I25 Misc. 805, 212 N. Y. Supp. 72 (1925); Fralich v. Despar, I65 
promise by the employee not to compete will be bad if the restraint is more extensive territorially than is reasonably necessary to protect the employer's business, $i$. e., if it extends beyond the limits to which the business actually extends or by reasonable allowance may be extended, ${ }^{84}$ or if the restraint is for a length of time not needed to protect the employer's business. ${ }^{95}$ Nor will equity enjoin the breach of a negative covenant not to enter into the employment of a competitor, where the purpose is to prevent the employee from quitting the employer's service and not to prevent use of detrimental information gained through employment. ${ }^{96}$

Pa. 26, 30 Atl. 52I (I894) ; Stoflet v. Stoflet, I60 Pa. 532, 28 Atl. 857 (I894); Turner v. Abbott, II6 Tenn. 718. 94 S. W. 64 (1906); Eureka Ldy. Co. v. Long, I46 Wis. 205, I3I N. W. 412 (IgII); Jewel Tea Co. v. Novak, I46 Wis. 224, I3I N. W. 4I5 (I9II).

"The Samuel Stores v. Aaron H. Abrams, 94 Conn. 248, I08 Atl. 54 I (1919); Simms v. Burnette, 55 Fla. 702, 46 So. 90 (I908); Victor Chemical Works v. Iliff, 299 Ill. 532, I32 N. E. 806 (I92I); Sherman v. Pfefferkọrn, 24I Mass. 468, I35 N. E. 568 (r922); Grand Union Tea Co. v. Levitsky, I53 Mich. 244, 116 N. W. 1090 (1908); Osius v. Hinchman, 150 Mich 603, I14 N. W. 402 (I908); Dow Chemical Co. v. Am. Bromine Co., 210 Mich. 262, I77 N. W. 996 (1920); Mallinckrodt Chemical Works v. Nemnich, I69 Mo. 389, 69 S. W. 355 (1902) ; Steinmeyer v. Phenix Cheese Co., 9r N. J. L. 35I, I02 At1. I50 (I9I7); Kaumagraph Co. v. Stampagraph Co., 235 N. Y. I, I38 N. E. 485 (I923); Hammerstein v. Mann, I37 App. Div. 580, I22 N. Y. Supp. 276 (1910) ; Magid v. Tannenbaum, I64 App. Div. 142, I49 N. Y. Supp. 445 (19r4); Gilbert v. Wilmer, I02 Misc. 388, 168 N. Y. Supp. 1043 (I9I8); Kaumagraph Co. v. Stampagraph, 197 App. Div. 66, 188 N. Y. Supp. 678 (I92I) ; Keeler v. Taylor, $53 \mathrm{~Pa} .467$ (I866); Iron City Laundry Co. v. Leyton, 55 Pa. Super. 93 (I9I3) ; Chain Belt Co. v. Spreckelsen, II7 Wis. 106, 94 N. W. 78 (I903).

${ }_{85}$ A. Booth \& Co. v. Davis, 127 Fed. 875, mod. I3I Fed. 31 (C. C. A. 6th, I904); Tuscaloosa Ice Mfg. Co. v. Williams, I27 Ala. IIo, 28 So. 669 (1900); Sauser v. Kearney, I47 Iowa 335, I26 N. W. 322 (1910); Keene Syndicate v. Wichita Gas, Electric \& Power Co., 69 Kan. 284, 76 Pac. 834 (1904); Barrone v. Mosely Bros., I44 Ky. 698, I39 S. W. 869 (I9II) ; Conemaugh Gas Co. v. Jackson Farne Gas Co, $186 \mathrm{~Pa}$. 443, 40 At1. 1000 (1898); Boggs v. Friend, 77 W. Va. 494,87 S. E. 876 (IgI6); Kradwell v. Thiesen, I3I Wis. 97, III N. W. 233 (I907).

${ }^{\infty}$ Clark Paper Co. v. Stenacher, 236 N. Y. 3I2, I40 N. E. 708 (I922). 